\title{
MATERNITY UNIT ADMISSIONS POLICY AND THE USE OF SIMULATIONS
}

\author{
M. W. BEAVER, M.B., B.S., D.P.H. \\ Deputy County Medical Officer, Nottinghamshire County Council
}

A VERY noticeable feature of the development of the obstetric services in the United Kingdom during the past 20 years has been the emphasis on the importance of hospital confinements in reducing the incidence of maternal deaths and perinatal infant deaths. The extent to which the need for a hospital confinement is urged varies between the rather subdued statements of the triennial Reports on the Confidential Enquiries into Maternal Deaths (1963, 1966, 1969), which stress the need for proper selection of cases for a domiciliary confinement, the Report of the Maternity Services Committee (1959), and those who appear to take the view that all births should be in hospital (Peel, 1968; Morison, 1969; Baird, 1969; Yellowlees, 1969).

Although many believe that a domiciliary maternity service still has a part to play, there has been throughout the country an increase, which shows no signs of coming to an end, in the proportion of confinements in hospital (Figure). In part, this has been the product of an increase in available maternity beds and a reduction in the statutory minimum period of the puerperium, but a much more important factor has been the increase of early dis- charges from hospital, that is, the patient is discharged before she is considered to have ceased to be in need of nursing care from a practising midwife.

\section{Early Discharge Procedures}

The policy of early discharge is now generally practised in this country. It can take either of two forms, but it is difficult to estimate to what extent the use of one form precludes the use of the other. Often a combination of the two procedures is used.

In the first of these the patient is admitted to hospital with the intent that she will stay 10 days if there are beds available but, if not, she is discharged before this, perhaps as early as the fifth day of her puerperium. In essence, the patient does not know when she is going home, although obviously it is preferable that, if the mother is to be discharged early, the decision should have been taken early in her pregnancy and should be acceptable to all involved, i.e., patient, family doctor and local authority (Ministry of Health, 1965).

The second group of early discharges are the elective ones. A patient is booked for a hospital confinement on the understanding that she will be

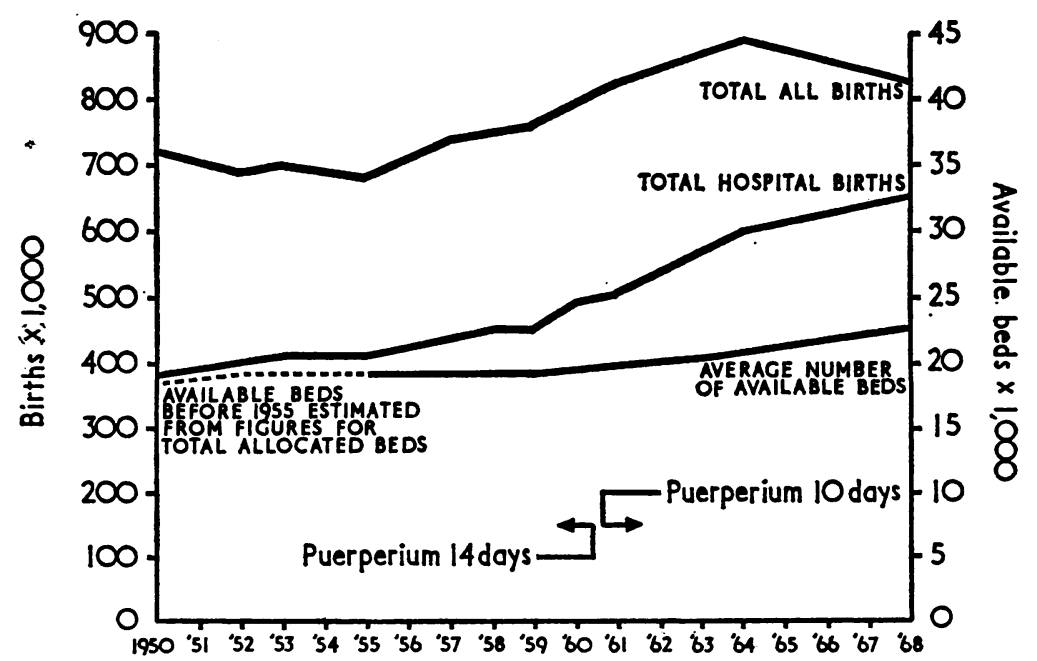

Froure. Live and still births and available maternity beds, England and Wales, yearly totals 1950-68. 
discharged early on a specified day. The most usual but not the only form which such elective early discharge arrangements can take is the 48-hour discharge procedure. This was pioneered in the City of Bradford where insufficient hospital beds and a large number of births in socio-economic groups with an adverse perinatal mortality experience led to its adoption and subsequent detailed study and exposition (Douglas, Edgar and Horne, 1961; Arthurton and Bamford, 1967; Craig and Muirhead, 1967).

\section{Admission and Discharge Policy in Maternity UNITS}

If early discharges are considered to be a necessity it is desirable that the admission and discharge policy in any particular area should be carefully formulated following discussion between representatives of hospitals, family doctors, and local health authorities. In such a formulation the obvious first step is to look at the total annual births and to determine what proportion will require hospital admission (Ministry of Health, 1959). One can proceed from previous years' admissions or, if a new unit with more beds is being opened, one may have to make a theoretical assessment. The first step, if this is done, is to tabulate births according to maternal age, parity, and social class, and then to apply the data available in studies on infant mortality, e.g., from the General Register Office (Heady and Heasman, 1959; Spicer and Lipworth, 1966) or from the Perinatal Mortality Survey (Butler and Bonham, 1963). Initial criteria for a hospital confinement can be set, e.g., all groups with a mortality ratio more adverse than 100 .

Local health authorities receive summaries of each year's births in their areas from the Department of Health and Social Security, tabulated according to the mother's age and parity. Unfortunately, mother's social class, an important component in selecting at risk groups (Spicer and Lipworth, 1966), is omitted from this tabulation.

The second component of the theoretical requirements is the number of expected admissions for obstetric abnormality. This could be derived from previous years' admissions. A proportion of this group would be included in the first component and should not be counted twice.

The third component is made up of patients who would not be booked under the above criteria but who require a hospital bed on social grounds. An estimate can be made by examining applications for social bookings made in previous years.

Having made an initial estimate of requirements, one must determine if the available facilities can satisfy the estimated need. If they do not, the criteria used in components one and three above will have to be reset, bearing in mind that these criteria are relative ones. Before discussing how one can assess whether the available beds are sufficient for this initial estimate, one should consider what requirements should be satisfied by an agreed policy.

Aside from the general desire of all to see a maternity service which is safe for both mother and child, there are quite a number of other requirements which are of practical importance.

The consultant obstetrician, family doctor, and domiciliary midwife will want an admission policy which ensures that all women showing any abnormality, either antenatally or during labour, can be admitted to an obstetric unit. They will also wish to see patients in high-risks groups booked for hospital confinement. The domiciliary midwife will want to see an admission policy which ensures that she does not have to deliver or nurse a woman in a house lacking modern facilities or with other adverse social circumstances.

In most areas, satisfying these requirements means introducing early discharge in some form or other. However, there is a danger that unless this is carefully planned and controlled, domiciliary staff will lose interest and become increasinglyo difficult to recruit and retain. The ratio between home confinements and early discharges must be such that domiciliary midwives conduct enough deliveries to maintain professional skills.

It also follows that there should be the maximum possible bed occupancy. Effecting this reduces the early discharge nursing load on domiciliary services and can produce an actual financial saving for the National Health Service.

The Health Services and Public Health Act, 1968, has given local authorities powers to arrange for domiciliary midwives to conduct deliveries in hospital. Where the circumstances are appropriate this can go a long way to solving the problem of loss of skills by the midwife. However, arrangements of this kind are practical only if the hospital unit is close to the area in which the midwife works and even then do not remove the need for a careful control of the early discharge rate.

What does the patient herself want? Alment, Barr, Reid, and Reid (1967), in their series of 503 normal confinements in Northamptonshire, showed a preference for home confinement among the $\mathbf{2 1 2}$ women who had had experience of both hospital and home. The lesson to be learned from this survey is, perhaps, that the patient's wish is that childbirth should not be an unpleasant experience. It seems reasonable to suggest that one factor in 
achieving this end is continuity of care during pregnancy, childbirth, and puerperium. This can be provided within an early discharge system if the implications have been worked out and the possible results have been carefully evaluated.

Summing up these requirements, it is suggested that an admission policy should

(1) maximize admissions,

(2) maximize bed occupancy, and

(3) minimize unscheduled early discharges, subject to the following constraints:

The ratio of early discharges to domiciliary confinements should not exceed a pre-determined figure.

The early discharge procedure should not be used in individual cases unless all parties consider its application to be appropriate.

\section{Simulation of the Admission and Discharge EXPERIENCE OF A MATERNITY UNIT}

How can these requirements be satisfied? (1), (2) and (3) are bound together in a very complex relationship which can defeat the best intentions. The method used here to study this relationship is simulation, using an artificial sequence of admissions to the postnatal wards of an obstetric unit. This method is sometimes referred to as the "Monte Carlo Method'.

Certain assumptions have been made about the hypothetical obstetric units postulated in each simulation. These will now be considered but the justification or not of these assumptions does not detract from the fact that a model of this sort can give us a great deal of insight into the working of a system, even such a system as theoretically simple as

\section{HOME $\longrightarrow$ HOSPITAL $\longrightarrow$ HOME}

(1) Beds for antenatal care are kept separate from the rest of the unit and consequently are disregarded in a simulation. This corresponds generally to reality except where an obstetric unit is very small.

(2) It is assumed that admissions are distributed randomly. However, if there is a clearly defined pattern of admissions, due to some local factor, it can be introduced into a simulation.

(3) No patient stays longer than 10 days after delivery. This is a simplification which allows a practical analysis to be made. The fact that there are usually departures from this does not invalidate the basic procedure. Published data indicate that the average proportion of postnatal patients, with a stay exceeding 10 days, is in the region of $5 \%$ in non-teaching hospitals (Godber, 1968).

(4) It is assumed that admissions and discharges all take place at the same time each day, that is, the unit can exceed its total permitted patients within the 24-hour period but this must be put right by the end of the period.

\section{First Example of a Simulation-Long Stay OnLy}

The first worked out example of a simulation is a very simple one. A small maternity unit which has 22 beds, excluding beds devoted entirely to antenatal cases, admits patients with the intention that they should stay 10 days unless pressure on accommodation produces a need for an unscheduled early discharge. Patients are booked on the basis of $\mathbf{7 3 0}$ admissions per year. If all these admissions arrived at regular intervals, that is, two admissions per day, and were discharged 10 days later, then the bed occupancy would be $91 \%$.

The first step is to calculate the probabilities of 0 , $1,2,3,4$, etc. admissions in a day, and for this purpose the Poisson distribution is chosen as the one most suitable. This is in accordance with elementary queuing theory. The question whether this is an accurate representation of reality is discussed later.

The probabilities are calculated from the equation $P_{\mathrm{r}}=\boldsymbol{m}^{\mathrm{r}} e^{-\mathrm{m}} / \boldsymbol{r}$ ! where $r$ is the number of admissions $P_{\mathrm{r}}$ is the probability of $r$ admissions in one day, $\boldsymbol{m}$ is the average number of admissions in one day and $e$ is the base of natural logarithms. These probabilities are combined in a cumulative form and multiplied by 1,000 to give a range of three digit numbers corresponding to a range of admissions from 0 to 8 .

The method of converting the rectangular distri-

TABLE I

TABLE FOR DERIVING POISSON DISTRIBUTED ADMISSIONS FROM TABLES OF RANDOM NUMBERS Average daily admissions $\mathrm{m}=\mathbf{2 . 0 0}$

\begin{tabular}{|c|c|}
\hline Random No. & No. of Patients Admitted \\
\hline $\begin{array}{r}1 \text { to } 135 \\
136 \text { to } 406 \\
407 \text { to } 677 \\
678 \text { to } 857 \\
858 \text { to } 947 \\
948 \text { to } 983 \\
984 \text { to } 995 \\
996 \text { to } 999 \\
000\end{array}$ & $\begin{array}{l}0 \\
1 \\
2 \\
3 \\
4 \\
5 \\
6 \\
7 \\
8\end{array}$ \\
\hline
\end{tabular}

bution of random numbers to a Poisson distribution of admissions with an expectation of 2 is shown in Table I.

Using a table of random numbers a series of day's admissions to this unit is simulated. This is set out in Table II, from which one can see what fluctuations there are in the numbers of occupied 
TABLE II

EXTRACT FROM FIRST SIMULATION-ADMISSIONS TO AND DISCHARGES FROM POSTNATAL WARDS OF A MATERNITY UNIT

Average daily admission $=2 \cdot 00$, Total beds available $=22$

\begin{tabular}{|c|c|c|c|c|c|c|c|c|}
\hline Day & $\begin{array}{c}\text { Random } \\
\text { No. }\end{array}$ & Admissions & $\begin{array}{c}\text { Beds } \\
\text { Occupied } \\
\text { Start }\end{array}$ & $\begin{array}{l}\text { Theoretical } \\
\text { Discharges }\end{array}$ & Correction & $\begin{array}{c}\text { Beds } \\
\text { Occupied } \\
\text { End }\end{array}$ & $\begin{array}{c}\text { Beds } \\
\text { Vacant } \\
\text { End }\end{array}$ & $\underset{\text { Discharges }}{\text { Early }}$ \\
\hline \multirow[t]{2}{*}{$\begin{array}{l}51 \\
52 \\
53 \\
54 \\
55 \\
56 \\
57 \\
58 \\
59 \\
60\end{array}$} & $\begin{array}{l}321 \\
848 \\
722 \\
081 \\
239 \\
825 \\
501 \\
131 \\
819 \\
045\end{array}$ & $\begin{array}{l}\mathbf{1} \\
\mathbf{3} \\
\mathbf{3} \\
\mathbf{0} \\
\mathbf{1} \\
\mathbf{3} \\
\mathbf{2} \\
\mathbf{0} \\
\mathbf{3} \\
\mathbf{0}\end{array}$ & $\begin{array}{l}17 \\
14 \\
14 \\
15 \\
14 \\
14 \\
16 \\
18 \\
15 \\
18\end{array}$ & $\begin{array}{l}4 \\
3 \\
2 \\
1 \\
1 \\
1 \\
0 \\
3 \\
0 \\
2\end{array}$ & & $\begin{array}{l}14 \\
14 \\
15 \\
14 \\
14 \\
16 \\
18 \\
15 \\
18 \\
16\end{array}$ & $\begin{array}{l}8 \\
8 \\
7 \\
8 \\
8 \\
6 \\
4 \\
7 \\
4 \\
6\end{array}$ & \\
\hline & & 16 & & 17 & & 154 & 66 & \\
\hline \multirow[t]{2}{*}{$\begin{array}{l}61 \\
62 \\
63 \\
64 \\
65 \\
66 \\
67 \\
68 \\
69 \\
70\end{array}$} & $\begin{array}{l}222 \\
741 \\
971 \\
960 \\
162 \\
713 \\
993 \\
872 \\
275 \\
528\end{array}$ & $\begin{array}{l}1 \\
3 \\
5 \\
5 \\
1 \\
3 \\
6 \\
4 \\
1 \\
2\end{array}$ & $\begin{array}{l}16 \\
16 \\
16 \\
18 \\
22 \\
22 \\
22 \\
22 \\
22 \\
22\end{array}$ & $\begin{array}{l}1 \\
3 \\
3 \\
0 \\
1 \\
3 \\
2 \\
0 \\
3 \\
0\end{array}$ & $\begin{array}{ll}1 & \\
1 & \\
1 & \\
0 & 5 \\
3 & 6 \\
0 & 7\end{array}$ & $\begin{array}{l}16 \\
16 \\
18 \\
22 \\
22 \\
22 \\
22 \\
22 \\
22 \\
22\end{array}$ & $\begin{array}{l}6 \\
6 \\
4 \\
0 \\
0 \\
0 \\
0 \\
0 \\
0 \\
0\end{array}$ & $\begin{array}{l}1 \\
1 \\
1 \\
5 \\
4 \\
1 \\
2\end{array}$ \\
\hline & & 31 & & 16 & & 204 & 16 & 15 \\
\hline \multirow[t]{2}{*}{$\begin{array}{l}71 \\
72 \\
73 \\
74 \\
75 \\
76 \\
77 \\
78 \\
79 \\
80\end{array}$} & $\begin{array}{l}466 \\
598 \\
449 \\
943 \\
730 \\
025 \\
934 \\
539 \\
188 \\
708\end{array}$ & $\begin{array}{l}2 \\
2 \\
2 \\
4 \\
3 \\
0 \\
4 \\
2 \\
1 \\
3\end{array}$ & $\begin{array}{l}22 \\
22 \\
22 \\
22 \\
22 \\
22 \\
22 \\
22 \\
22 \\
22\end{array}$ & $\begin{array}{l}1 \\
3 \\
5 \\
5 \\
1 \\
3 \\
6 \\
4 \\
1 \\
2\end{array}$ & $\begin{array}{ll}1 & 8 \\
3 & 7 \\
5 & 4 \\
5 & 1 \\
1 & 4 \\
3 & 4 \\
4 & \\
2 & \end{array}$ & $\begin{array}{l}22 \\
22 \\
22 \\
22 \\
22 \\
22 \\
22 \\
22 \\
22 \\
22\end{array}$ & $\begin{array}{l}\mathbf{0} \\
\mathbf{0} \\
\mathbf{0} \\
\mathbf{0} \\
\mathbf{0} \\
\mathbf{0} \\
\mathbf{0} \\
\mathbf{0} \\
\mathbf{0} \\
\mathbf{0}\end{array}$ & $\begin{array}{l}2 \\
2 \\
2 \\
4 \\
3 \\
0 \\
2\end{array}$ \\
\hline & & 23 & & 31 & & 220 & 0 & 16 \\
\hline
\end{tabular}

The column entitled Correction is the carry over of patients discharged early. It is divided into two-the first figure is patients who would have been discharged on that day-the second figure is patients who would have been discharged on subsequent days. The first figure is deducted from the theoretical discharge for that day.

Summary of results from Table II

Total admissions

Total discharges

Total early discharges

Early discharges as percentage of all discharges

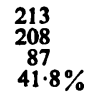

beds and what proportion of patients are discharged early, that is before 10 days.

One hundred and ten separate days are simulated and from this is obtained the experience of 100 days. The first 10 days' experience is not used in the final calculations. It is considered that starting conditions have been achieved at the end of this period.

The bed occupancy for the simulation was $87.8 \%$. Admissions were 213 as compared with a theoretical admission total of 200 . Approximately $42 \%$ of all patients were discharged before the tenth day. Average length of stay for early discharge patients was eight days.

\section{Second Example of a Simulation-Mixed Long-} STAY AND 48-HOUR

The second model is one also with 22 lying-in

Total bed days

Bed occupancy

Average stay for patients discharged early

1,932

$87.8 \%$

8.0 days beds. Instead of a policy of all 10-day admissions, there is a mixture of 10-day and 48-hour admissions (Table III).

All 48-hour admissions are discharged in the second 24-hour period following the admission day. The sequence of admissions is generated in the same way as described for the first model. The average admission rate for patients booked for 10 days is 1.5 per day and that for patients booked for 48 hours is 2.0 per day. If these patients were admitted at this rate, that is, if they all arrived at regular intervals then the bed occupancy would be $86.5 \%$. The simulation is worked out again for 110 days, that is $\mathbf{1 0 0}$ days after the initial 'filling-up' period. Results of this simulation are set out at the foot of Table III. Bed occupancy is $84.5 \%$ and the average stay in hospital is 5.3 days. This is a figure close to 
TABLE III

EXTRACT FROM SECOND SIMULATION-MIXED LONG AND SHORT-STAY ADMISSIONS TO THE POSTNATAL WARDS OF A MATERNITY UNIT

Beds available $=22$ Average daily admission: 10 day $=1 \cdot 50,48$ hour $=2.0$

\begin{tabular}{|c|c|c|c|c|c|c|c|c|c|c|c|c|}
\hline \multirow{2}{*}{$\begin{array}{l}\text { Day } \\
41 \\
42 \\
43 \\
44 \\
45 \\
46 \\
47 \\
48 \\
49 \\
50 \\
\end{array}$} & \multirow{2}{*}{$\begin{array}{c}\begin{array}{c}\text { Random } \\
\text { No. } \\
10-d y \\
\text { Admissions }\end{array} \\
542 \\
000 \\
804 \\
248 \\
393 \\
470 \\
955 \\
190 \\
794 \\
585\end{array}$} & \multirow{2}{*}{$\begin{array}{c}\begin{array}{c}\text { 10-day } \\
\text { Admissions }\end{array} \\
1 \\
7 \\
2 \\
1 \\
1 \\
1 \\
4 \\
0 \\
2 \\
2\end{array}$} & \multirow{2}{*}{\begin{tabular}{|c}
$\begin{array}{c}\text { Random } \\
\text { No. } \\
\text { 48.hr. } \\
\text { Admissions }\end{array}$ \\
965 \\
359 \\
869 \\
739 \\
435 \\
285 \\
542 \\
332 \\
417 \\
640
\end{tabular}} & \multirow{2}{*}{$\begin{array}{c}\begin{array}{c}\text { 48-hr. } \\
\text { Admissions }\end{array} \\
5 \\
1 \\
4 \\
3 \\
2 \\
1 \\
2 \\
1 \\
2 \\
2\end{array}$} & \multirow{2}{*}{$\begin{array}{c}\begin{array}{c}\text { Beds } \\
\text { Occupied } \\
\text { Start }\end{array} \\
17 \\
19 \\
22 \\
21 \\
22 \\
21 \\
18 \\
21 \\
21 \\
22\end{array}$} & \multirow{2}{*}{$\begin{array}{c}\begin{array}{c}\text { Theoretical } \\
\text { 10-day } \\
\text { Discharges }\end{array} \\
1 \\
1 \\
3 \\
1 \\
1 \\
2 \\
1 \\
0 \\
1 \\
0\end{array}$} & \multicolumn{2}{|c|}{ Correction } & \multirow{2}{*}{$\begin{array}{c}\begin{array}{c}\text { 48-hr. } \\
\text { Discharges }\end{array} \\
3 \\
3 \\
5 \\
1 \\
4 \\
3 \\
2 \\
1 \\
2 \\
1\end{array}$} & \multirow{2}{*}{\begin{tabular}{|c|}
$\begin{array}{c}\text { Beds } \\
\text { Occupied } \\
\text { End }\end{array}$ \\
19 \\
22 \\
21 \\
22 \\
21 \\
18 \\
21 \\
21 \\
22 \\
22 \\
\end{tabular}} & \multirow{2}{*}{$\begin{array}{c}\begin{array}{c}\text { Beds } \\
\text { Vacant } \\
\text { End }\end{array} \\
3 \\
0 \\
1 \\
0 \\
1 \\
4 \\
1 \\
1 \\
0 \\
0\end{array}$} & \multirow{2}{*}{$\begin{array}{c}\begin{array}{c}\text { Early } \\
\text { Discharge }\end{array} \\
1 \\
1 \\
\\
3\end{array}$} \\
\hline & & & & & & & \multicolumn{2}{|l|}{$\begin{array}{l}1 \\
1\end{array}$} & & & & \\
\hline & & 21 & & 23 & & 11 & & & 11 & 209 & 11 & 5 \\
\hline \multirow[t]{2}{*}{$\begin{array}{l}51 \\
52 \\
53 \\
54 \\
55 \\
56 \\
57 \\
58 \\
59 \\
60\end{array}$} & $\begin{array}{l}114 \\
715 \\
000 \\
984 \\
753 \\
043 \\
441 \\
136 \\
552 \\
637\end{array}$ & $\begin{array}{l}0 \\
2 \\
7 \\
5 \\
2 \\
0 \\
1 \\
0 \\
1 \\
2\end{array}$ & $\begin{array}{l}088 \\
367 \\
312 \\
756 \\
847 \\
189 \\
842 \\
052 \\
259 \\
685\end{array}$ & $\begin{array}{l}0 \\
1 \\
1 \\
3 \\
3 \\
1 \\
3 \\
0 \\
1 \\
\mathbf{1}\end{array}$ & $\begin{array}{l}22 \\
20 \\
16 \\
22 \\
22 \\
22 \\
20 \\
21 \\
20 \\
19\end{array}$ & $\begin{array}{l}1 \\
7 \\
2 \\
1 \\
1 \\
1 \\
4 \\
0 \\
2 \\
2\end{array}$ & $\begin{array}{l}\frac{1}{2} \\
\\
1 \\
1 \\
4 \\
0 \\
2 \\
2\end{array}$ & $\begin{array}{l}2 \\
\\
5 \\
8 \\
4 \\
4 \\
2\end{array}$ & $\begin{array}{l}2 \\
2 \\
0 \\
1 \\
1 \\
3 \\
3 \\
1 \\
3 \\
0\end{array}$ & $\begin{array}{l}20 \\
16 \\
22 \\
22 \\
22 \\
20 \\
21 \\
20 \\
19 \\
22\end{array}$ & $\begin{array}{l}\mathbf{2} \\
\mathbf{6} \\
0 \\
\mathbf{0} \\
\mathbf{0} \\
\mathbf{2} \\
\mathbf{1} \\
\mathbf{2} \\
\mathbf{3} \\
\mathbf{0}\end{array}$ & $\begin{array}{l}6 \\
4\end{array}$ \\
\hline & & 20 & & 16 & & 21 & & & 16 & 204 & 16 & 12 \\
\hline \multirow[t]{2}{*}{$\begin{array}{l}\mathbf{6 1} \\
\mathbf{6 2} \\
63 \\
64 \\
65 \\
66 \\
67 \\
68 \\
69 \\
70\end{array}$} & $\begin{array}{l}871 \\
957 \\
474 \\
576 \\
226 \\
722 \\
725 \\
839 \\
899 \\
053\end{array}$ & $\begin{array}{l}\mathbf{3} \\
\mathbf{4} \\
1 \\
\mathbf{2} \\
\mathbf{1} \\
\mathbf{2} \\
\mathbf{2} \\
\mathbf{3} \\
\mathbf{3} \\
\mathbf{0}\end{array}$ & $\begin{array}{l}712 \\
330 \\
531 \\
923 \\
345 \\
229 \\
328 \\
209 \\
025 \\
195\end{array}$ & $\begin{array}{l}3 \\
1 \\
2 \\
4 \\
1 \\
1 \\
1 \\
1 \\
0 \\
1\end{array}$ & $\begin{array}{l}22 \\
22 \\
22 \\
22 \\
22 \\
20 \\
19 \\
20 \\
22 \\
22\end{array}$ & $\begin{array}{l}0 \\
2 \\
7 \\
5 \\
2 \\
0 \\
1 \\
0 \\
1 \\
2\end{array}$ & $\begin{array}{l}0 \\
2 \\
7\end{array}$ & & $\begin{array}{l}1 \\
3 \\
3 \\
1 \\
2 \\
4 \\
1 \\
1 \\
1 \\
1\end{array}$ & $\begin{array}{l}22 \\
22 \\
22 \\
22 \\
20 \\
19 \\
20 \\
22 \\
22 \\
22\end{array}$ & $\begin{array}{l}\mathbf{0} \\
\mathbf{0} \\
\mathbf{0} \\
\mathbf{0} \\
\mathbf{2} \\
\mathbf{3} \\
\mathbf{2} \\
\mathbf{0} \\
\mathbf{0} \\
\mathbf{0}\end{array}$ & $\frac{1}{2}$ \\
\hline & & 21 & & 15 & & 20 & & & 18 & 213 & 7 & 10 \\
\hline
\end{tabular}

Summary of results from Table III

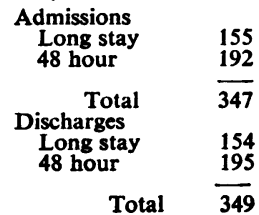

Total bed days

Total early discharges among long-stay patients

Early discharges as percentage of all long itay discharges

Average stay for long stay patients discharged early

Average stay all patients

1,859

$84.5 \%$

$41.6 \%$

5.3 days that suggested by McEwan (1967) as a guide to future planning of resources. The average stay for patients booked for 10 days is $8 \cdot 2$ days. Despite a great increase in admissions, this strategy does not avoid unscheduled early discharges and the bed occupancy has fallen.

Both these simulations show the functioning of a given admission rate and give some indication of the sort of response which would be obtained. However, the accuracy is unknown. Repeat simulations suggest that it is reasonably accurate for assessing 'bed occupancy' but due to differences in samples of random numbers, there is quite a marked variation in the response of the system insofar as 'early discharges' are concerned.

\section{VARIANCE REDUCING}

There are two methods of producing more accurate results with such simulations. They are (1) use of a computer (Tocher, 1963), and (2) variance reducing techniques.

To use a computer is at present not a practical solution. It should be pointed out, however, that it is quite possible to write a programme which would have wide application for this particular purpose.

The obvious variance reducing technique to use is the method of antithetic variates (Hammersley and Handscomb, 1964). This method is illustrated by the following simple example. In this simulation the number of beds is 38 , all patients are discharged at 10 days unless an early discharge is necessary, 
there are no elective early discharges and the average daily admission rate is $3 \cdot 5$. After simulation of 110 days the run is repeated using the same sequence of random numbers but the relationship is inverted. As the value of the random number increases so the admissions decrease but the probability of ' $r$ ' admissions in a day remains the same (Table IV).

TABLE IV

TABLE FOR DERIVING POISSON DISTRIBUTED ADMISSIONS FROM TABLES OF RANDOM NUMBERS Average daily admissions $m=3.50$

\begin{tabular}{c|c|c}
\hline Random No. (1) & Admission & Random No. (2) \\
\cline { 2 - 3 } $1-30$ & 0 & $971-000$ \\
$31-136$ & 1 & $865-970$ \\
$137-321$ & 2 & $680-864$ \\
$322-537$ & 3 & $464-679$ \\
$538-726$ & 4 & $275-463$ \\
$727-858$ & 5 & $143-274$ \\
$859-935$ & 6 & $66-142$ \\
$936-973$ & 7 & $28-65$ \\
$974-990$ & 8 & $11-27$ \\
$991-997$ & 9 & $4-10$ \\
$998-999$ & 10 & $2-3$ \\
000 & 11 & 1 \\
\hline
\end{tabular}

The results from these two runs are set out in Table V. The variance of the estimator $\frac{1}{2}\left(t+t^{\prime}\right)$ in the third column of Table $\mathrm{V}$ is less than one derived from two similar but unrelated runs of 100 days.

TABLE V

SUMMARY OF RESULTS FROM THIRD SIMULATION OF ADMISSIONS TO AND DISCHARGES FROM POSTNATAL WARDS OF A MATERNITY UNIT, LONG STAY BEDS ONLY

Beds available $=38 \quad$ Average daily admissions $=3.5$ $t=$ results from first run of 100 days

$\mathfrak{t}^{\prime}=$ results from second antithetic run of 100 days

\begin{tabular}{l|c|c|c}
\hline & $\mathrm{t}$ & $\mathrm{t}^{\prime}$ & $\frac{1}{2\left(\mathrm{t}+\mathrm{t}^{\prime}\right)}$ \\
\cline { 2 - 4 } & 340 & 354 & 347 \\
Ddmissions & 344 & 349 & 347 \\
Earlyarges & 40 & 77 & 59 \\
$\begin{array}{l}\text { Early discharges } \\
\text { of all discharges as percentage }\end{array}$ & $11.6 \%$ & $22.0 \%$ & $16.9 \%$ \\
$\begin{array}{l}\text { Bed occupancy } \\
\text { Average stay for patients } \\
\text { discharged early }\end{array}$ & $89 \%$ & $90 \%$ & $90 \%$ \\
\hline
\end{tabular}

These results prompt the question: Do these two runs give a subjectively accurate prediction of events, allowing for the obvious simplifications which are inherent in all simulations?

One Year's Admissions to the Postnatal Wards OF A MATERnItY UNIT. To give an answer to this, one year's admissions to the postnatal wards of a maternity unit were examined. The basic data are set out in Table VI.

The first question is: Is the distribution of daily admissions in accordance with the theoretical model, that is a Poisson distribution with a mean of
TABLE VI

DISTRIBUTION OF ONE YEAR'S ADMISSIONS TO THE POSTNATAL WARDS OF A MATERNITY UNIT BY MONTH

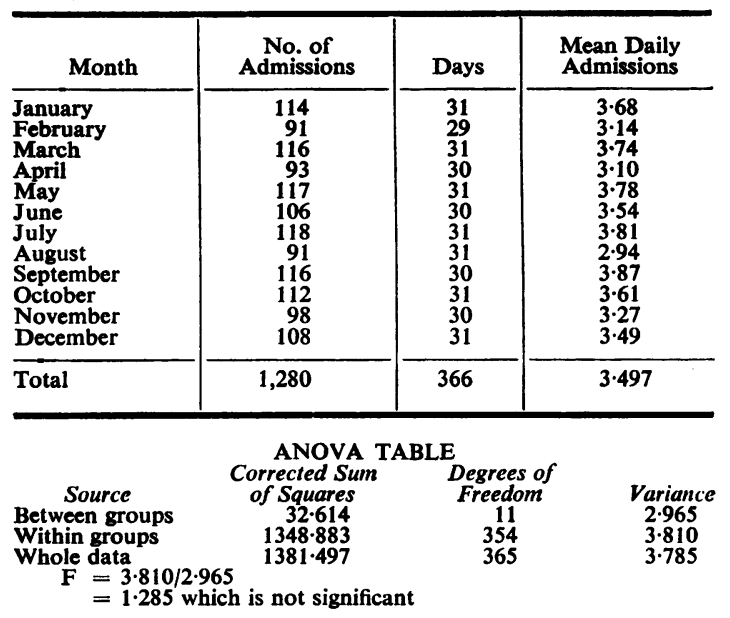

3.50? Table VII shows the distribution of daily admissions with the theoretical distribution for comparison.

The variance of the daily admissions is 3.785 , which is close to the mean of 3.497 , giving aid $\overrightarrow{0}$ index of dispersion of 1.08. This is in accordance with the hypothesis of a Poisson distribution. Foō $\chi^{2}$ test of dispersion, $\chi^{2}{ }_{365}=395.05$, which under the null hypothesis is not significant at the $10 \%$ level. The $\chi^{2}$ goodness of fit test for Table VII gives the statistic $\chi_{9}^{2}=8.33$ which is, again, not significant at the $10 \%$ level.

Cowan and Roth (1964) have described similar data from a London teaching hospital and have fitted two series of births to Poisson distributed

\section{TABLE VII}

DISTRIBUTION OF DAILY ADMISSIONS TO POSTNATAL WARDS OF A MATERNITY UNIT COMPARED WITH POISSON DISTRIBUTED MODEL OF MEAN 3.50

\begin{tabular}{|c|c|c|c|c|c|}
\hline $\begin{array}{c}\text { No. of } \\
\text { Admissions }\end{array}$ & $\begin{array}{l}\text { Observed } \\
\text { Frequency } \\
\quad \mathbf{O} \\
\end{array}$ & $\begin{array}{l}\text { Estimated } \\
\text { Frequency } \\
\quad \mathbf{E}\end{array}$ & O-E & $(\mathrm{O}-\mathrm{E})^{2}$ & $(\mathrm{O}-\mathrm{E})^{2} / \mathrm{E}$ \\
\hline $\begin{array}{c}0 \\
1 \\
2 \\
3 \\
4 \\
5 \\
6 \\
7 \\
8 \\
9 \\
10 \stackrel{8}{2} 11\end{array}$ & $\begin{array}{l}11 \\
40 \\
68 \\
80 \\
75 \\
40 \\
26 \\
10 \\
9 \\
4 \\
3\end{array}$ & $\begin{array}{l}11 \cdot 05 \\
38.69 \\
67.72 \\
78.98 \\
69 \cdot 11 \\
48.39 \\
28.22 \\
14.09 \\
6 \cdot 19 \\
2.42 \\
1 \cdot 21\end{array}$ & $\begin{array}{r}-0.05 \\
1.31 \\
0.28 \\
1.02 \\
5.89 \\
-8.39 \\
-2.22 \\
-4.09 \\
2.81 \\
1.58 \\
1.79\end{array}$ & $\begin{array}{r}0.003 \\
1.716 \\
0.078 \\
1.040 \\
34.692 \\
70.392 \\
4.928 \\
16.728 \\
7.896 \\
2.496 \\
3.204\end{array}$ & $\begin{array}{l}0.000 \\
0.044 \\
0.001 \\
0.013 \\
0.502 \\
1.455 \\
0.175 \\
1.87 \\
1.276 \\
1.031 \\
2.647\end{array}$ \\
\hline Totals & 366 & 366.07 & -0.07 & & 8.331 \\
\hline \multicolumn{6}{|c|}{$\begin{array}{l}\text { Number of degrees of freedom }=9 \\
\qquad x^{2}=8 \cdot 33 \text { which is not significant at the } \\
10 \% \text { level }\end{array}$} \\
\hline
\end{tabular}


TABLE VIII

DISTRIBUTION OF ONE YEAR'S ADMISSIONS TO POSTNATAL WARDS OF A MATERNITY UNIT BY DAY OF THE WEEK AND COMPARISON WITH POISSON DISTRIBUTED MODEL

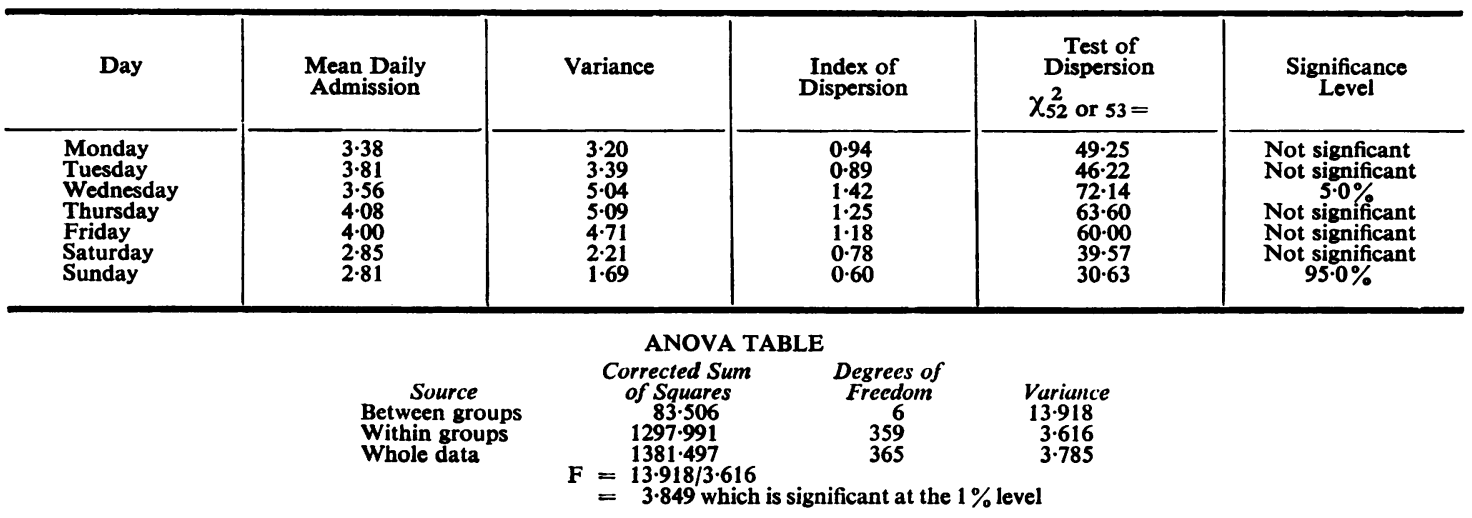

models. They quote two articles in support of this thesis (Thompson, Avant, and Spiker, 1960; Blumberg, 1961).

Tables VI and VIII show mean daily admissions by month and by day of the week. These findings were examined by analysis of variance. The values obtained for the $F$ test show that the difference from month to month is not statistically significant but that the difference from day to day of the week is significant at the $1 \%$ level.

If the observed data are entirely in accordance with the model, then the number of admissions for each day is independent of that for preceding or subsequent days. To explore the possibility that succeeding days' admissions were not independent, correlation coefficients were calculated between successive weekdays and are set out in Table IX. This shows that there are some departures from the postulated model but they are not sufficient to exclude its use as a working hypothesis. However, they do indicate that, in any given situation, it is necessary to examine the circumstances to ensure that there are not local factors producing a definite departure from randomness.

TABLE IX

ONE YEAR'S ADMISSIONS TO POSTNATAL WARDS OF MATERNITY UNIT: CORRELATION BETWEEN SUCCESSIVE WEEKDAYS

\begin{tabular}{|c|c|c|}
\hline Days & $\begin{array}{l}\text { Correlation } \\
\text { Coefficient }\end{array}$ & $\underset{\substack{\text { Level } \\
\text { Significance }}}{ }$ \\
\hline $\begin{array}{ll}\text { Monday } & \text { Tuesday } \\
\text { Tuesday } & \text { Wednesday } \\
\text { Wednesday } & \text { Thursday } \\
\text { Thursday } & \text { Friday } \\
\text { Friday } & \text { Saturday } \\
\text { Saturday } & \text { Sunday } \\
\text { Sunday } & \text { Monday } \\
\text { for all days }\end{array}$ & $\begin{array}{r}-0 \cdot 17 \\
-0 \cdot 09 \\
-0 \cdot 29 \\
0 \cdot 02 \\
0 \cdot 20 \\
0 \cdot 39 \\
0 \cdot 16 \\
0 \cdot 10\end{array}$ & $\begin{array}{l}\text { Not significant } \\
\text { Not significant } \\
H_{0}: P<0.01 \\
\text { Not significant } \\
\text { Not significant } \\
H_{0}: P<0.005 \\
\text { Not significant } \\
H_{0}: 0.02>P>0.01\end{array}$ \\
\hline
\end{tabular}

If there is none that is gross in effect, do simulations based on this simple model provide information of practical value?

As an attempt to provide an answer to this question the year's sequence of admissions was used to simulate a year's experience of admissions and discharges in a unit containing 38 postnatal beds on the basis of a 10-day stay. The results are set out in Table $X$. It can be seen that the estimate

TABLE X

SUMMARY OF RESULTS FROM SIMULATION OF A YEAR'S EXPERIENCE IN THE POSTNATAL WARDS OF A MATERNITY UNIT USING ACTUAL ADMISSIONS DATA

Total number of days

Admissions

Discharges

Early discharges

Early discharges as percentage of all discharges Average length of stay for early discharges Bed occupancy

\begin{tabular}{|c|c}
356 \\
1,245 \\
1,246 \\
243 \\
$19.5 \%$ \\
8.5 days \\
$89 \%$
\end{tabular}

provided by the two runs (Table $\mathrm{V}$ ) would have provided a forecast accurate enough for operational purposes.

\section{SUMMARY}

Maternity unit admission policy is discussed and it is argued that when early discharge is introduced it should be used as an elective procedure. It is suggested that the consequences of any policy that is contemplated should be worked out and discussed with all involved in its implementation. The method described for making an estimate of the performance of any given policy is simulation, using an artificial sample of admissions. The statistical model used is one in which daily admissions are distributed in a 
Poisson manner. Evidence is adduced to support the validity of this model by examining a year's admissions to a maternity unit. It is suggested that procedures similar to this can be used to formulate strategies for dealing with many problems encountered in the management of maternity units.

I should like to thank Dr. H. I. Lockett, County Medical Officer, and Mr. A. A. Bellaby, Systems Analyst, Nottinghamshire County Council, for their advice and encouragement.

The random numbers used in this paper were taken from the Lanchester Short Statistical Tables prepared by G. R. Braithwaite and C. O. D. Titmus and published by the English Universities Press Limited.

\section{REFERENCES}

Alment, E. A. J., Barr, A., Reid, Marjorie, and Reid, J. J. A. (1967). Normal confinement: a domiciliary and hospital study. Brit. med. J., $2,530$.

Arthurton, M. W., and Bamford, F. N. (1967). Paediatric aspects of the early discharge of maternity patients. Brit. med. J., 3, 517.

BAIRD, D. (1969). Perinatal mortality. Lancet, 1, 511.

BlumberG, M. S. (1961). 'DPF Concept' helps predict bed needs. Mod. Hosp., 97, No. 6 (Dec.), p. 75.

Butler, N. R., and BonhaM, D. G. (1963). Perinatal Mortality: The First Report of the 1958 Perinatal Mortality Survey. Livingstone, Edinburgh and London.

Cowan, P., and Roth, K. (1964). Determining maternity case load by means of a Poisson process. Brit. J. prev. soc. Med., 18, 105.

Craig, G. A., and Muirhead, J. M. B. (1967). Obstetric aspects of the early discharge of maternity patients. Brit. med. J., 3, 520.
Douglas, J., Edgar, W., and Horne, Kathleen (1961). The Bradford maternity scheme . Med. Offr., 106, 333. Godber, G. E. (1968). On the State of the Public Health: The Annual Report of the Chief Medical Officer of the Ministry of Health for the year 1967. H.M.S.O., London.

Hammersley, J. M., and Handscomb, D. C. (1964). Monte Carlo Methods. Methuen, London.

Heady, J. A., and Heasman, M. A. (1959). Social and Biological Factors in Infant Mortality. General Register Office. Studies on Medical and Population Subjects, No. 15. H.M.S.O., London.

McEwAN, E. D. (1967). The case for a new maternitybed ratio. Lancet, $1,489$.

Ministry of Health (1959). Hospital maternity services. Circular 21/59 and H.M. (59) 69.

- (1965). Early discharge of maternity patients. Circular 6/65 and H.M. (65) 32.

Morison, C. R. (1969). Letter: maternity services. Brit. med. J., 1, 251.

PEeL, J. (1968). Letter: G.P. obstetric units. Brit. med. J., 3, 678.

Reports on Confidential Enquiries into Maternal Deaths in England and Wales (1963, 1966 and 1969). H.M.S.O., London.

Report of the Maternity Services Committee (1959). H.M.S.O., London.

SPICER, C. C., and LipWORTH, L. (1966). Regional and Social Factors in Infant Mortality. General Registeo Office. Studies on Medical and Population Subjects No. 19. H.M.S.O., London.

Thompson, J. B., Avant, O. W., and SpIKer, E. D戸 (1960). How queuing theory works for the hospital. Mod. Hosp., 94, No. 3 (March), p. 75.

TOCHER, K. D. (1963). The Art of Simulation. Methuen, London.

YelLOWLEES, H. (1969). The boundaries of community medicine with the hospital services. Publ. Hlth (Lond.), 84, 18. 